\title{
Inequalities in income security in later age in Latin America
}

\author{
Armando Barrientos ${ }^{1}$
}

Suggested citation Barrientos A. Inequalities in income security in later age in Latin America. Rev Panam Salud Publica. $2021 ; 45: 085$. https://doi.org/10.26633/RPSP.2021.85

\begin{abstract}
This paper examines inequalities in income security in later age. Three dimensions of inequality are considered: (i) inequalities in access to income support across countries and types of schemes; (ii) inequalities in the level of support within countries; and (iii) trends in gender inequality. Scheme stratification reinforces inequalities across socioeconomic groups and gender. More egalitarian, and sustainable, outcomes in later age income security in Latin America require policy reforms aimed at the incorporation of excluded groups and the withdrawal of public subsidies supporting privileged retirees.
\end{abstract}

Keywords Socioeconomic factors; income; pensions; Latin America.

\section{BACKGROUND}

Historically, income security in later age has been the focus of social policy in Latin America. Industrialization in the postWorld War II period led to the spread of stratified occupational insurance funds providing a range of transfers and services to specific groups of workers, with old age pensions as their core (1). With an eye on the growing political incorporation of worker organizations, and pension fund reserves, governments engaged in the consolidation and expansion of pension schemes (2). Toward the end of the 20th century, structural adjustment policies sought to reduce public sector deficits by replacing pay-as-you-go occupational pension schemes with individual retirement plans modeled on the individual retirement accounts (IRAs) in the United States of America $(3,4)$. They consist of mandatory savings accounts managed by financial providers. At retirement, the account balances are released to secure an annuity. In the 21st century, a rapid expansion of tax-financed old age transfers in the region has helped reduce large deficits in income security in later age $(5,6)$.

Today, these three types of schemes-occupational pension schemes, individual retirement plans, and tax-financed old age transfers-are responsible for income security in later age. The

\footnotetext{
1 University of Manchester, Manchester, United Kingdom $\square$ Armando Barrientos, a.barrientos@manchester.ac.uk
}

focus of this paper is on the large inequalities in income security resulting from these schemes. The main objective of this article is to assess inequalities in income security schemes in the region. It examines the extent to which income security schemes reach the population of the countries in the region, the distribution of benefits and transfers across the population, and recent trends in gender inequalities.

\section{REACH}

It will prove useful to clarify the terminology employed below. Where possible, a distinction will be made between retirement benefits on the one hand-from occupational pension schemes and individual retirement plans-and old age transfers on the other; "retirement benefits" and "transfers" for short. ${ }^{1}$ Figure 1 shows the share of the population over 65 in receipt of retirement benefits and transfers for Latin American countries in 2015. Taking the region as a whole, 55\% of people

\footnotetext{
${ }^{1}$ The literature often distinguishes between "contributory" and "noncontributory" pensions (7). This is misleading because: (i) some occupational schemes do not require contributions from members, especially in the public sector and the military; (ii) most occupational schemes in the region receive large tax-financed subsidies; and (iii) older people pay taxes and therefore contribute to fund tax-financed old age transfers. This is especially apt for Latin America, where the vast majority of tax revenue comes from valueadded tax (VAT) and other taxes on consumption. Old age transfers do not require withdrawal from the labor market; they are not "retirement benefits."
} 
FIGURE 1. Reach of income security schemes in later age, share of population aged 65 and over in receipt of retirement benefits and old age transfers in 2015

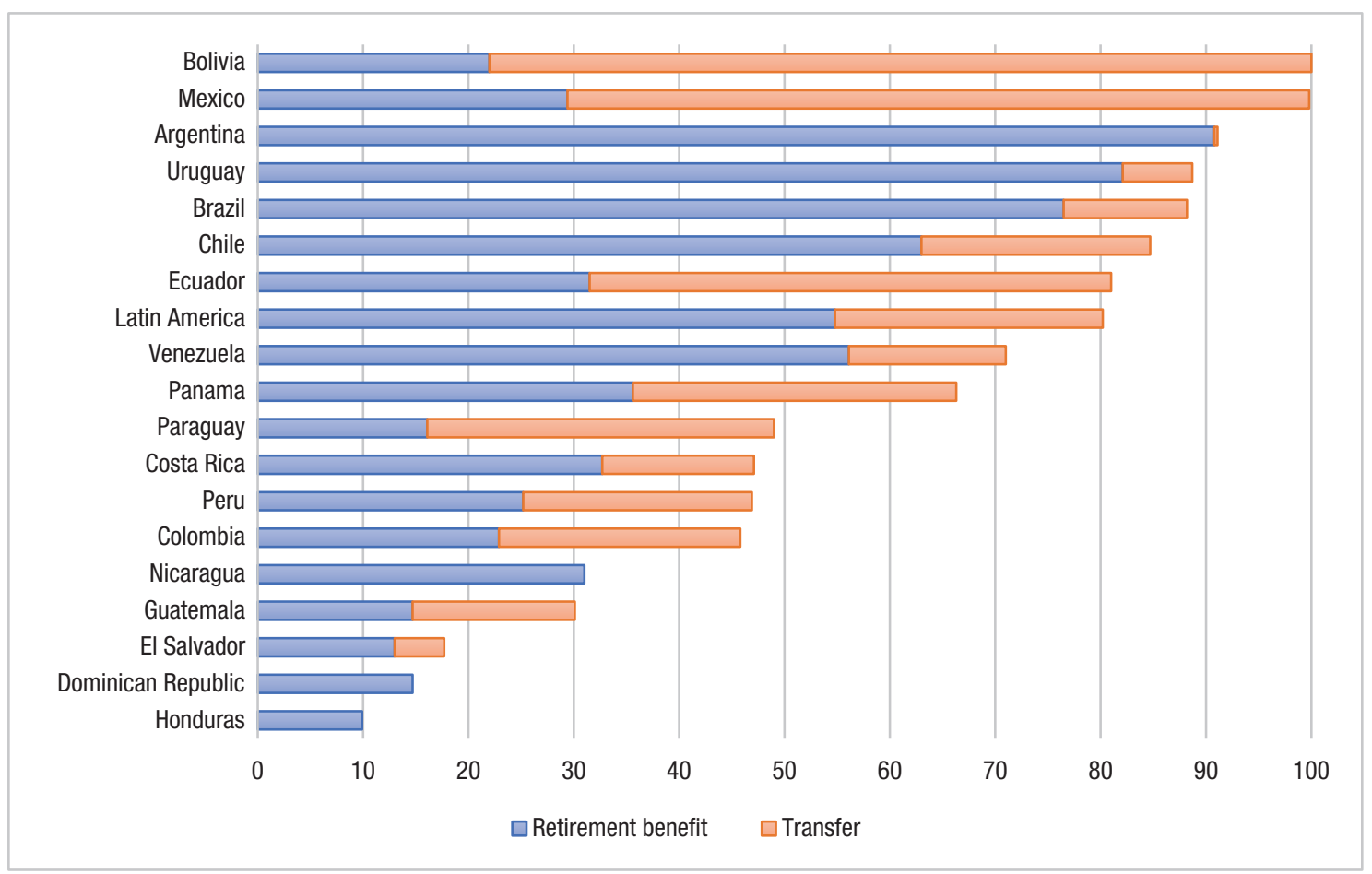

Source: Data from Arenas de Mesa (6) Table III.7 p.176 and Table III.12, p.193 (https://www.cepal.org/es/publicaciones/44851-sistemas-pensiones-la-encrucijada-desafios-la-sostenibilidad-america-latina). Retirement benefits include

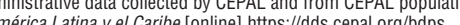

aged 65 and over were in receipt of retirement benefits and 25\% were in receipt of transfers. Overall, $80 \%$ of the relevant population in the region accessed some form of income support in 2015. This is a significant improvement when compared with earlier periods. In 2000 , only $52 \%$ of this demographic group had access to some form of income support, with $48 \%$ in receipt of a retirement benefit and $4 \%$ in receipt of a transfer (6). The large expansion in the reach of old age income support in the intervening period is a direct consequence of the rapid expansion of old age transfers. They reduced the gap in old age income support by 21 percentage points during this period. However, $20 \%$ of the population aged 65 and over were not reached by income security schemes in 2015.

Significant differences in reach persist across countries. In most Central American countries, as well as Paraguay, Peru, Colombia, and the Dominican Republic, less than half the population over 65 are able to access some form of income security. Countries with above average reach fall in two groups. Reach is high in more economically developed Southern Cone countries with longstanding occupational pension schemes, such as Argentina, Uruguay, and Brazil. Reach has risen fast in a second group of countries that have implemented large-scale old age transfer programs, such as Bolivia, Mexico, and Ecuador. Bolivia's transfer program reaches the population over 65 in full. This is interesting because it reveals alternative domestic strategies to establish comprehensive income security. Figure 1 shows separately the reach of retirement benefits and old age transfers. The upshot is that whereas in the past country differences in overall provision of later age income security had to do primarily with differences in the path of industrialization and economic development, today country differences in overall reach are mainly due to institutional and policy differences (8).

\section{INEQUALITIES IN THE LEVEL OF INCOME SUPPORT}

This section focuses on inequalities in income security within countries in Latin America. To capture this dimension of inequality, the analysis below reports on the distribution of retirement benefits and transfers combined using household survey data. Figure 2 shows "Pen's parade" graphs for selected countries. Pen (9) described income inequality by imagining a procession in which people's height would be proportional to their income. The procession would open with the smallest people, with the lowest income, followed by increasingly taller people, and end with a few giants. This device helps to represent the acute inequalities in income security among people aged 65 and over. To construct the panels, survey respondents aged 65 and over were selected and their incomes from all types of retirement benefits and transfers were added up. These observations were then ranked from lowest to highest for each country and divided into percentiles. The solid line in the panels tracks income levels for each percentile in domestic currency. To get a sense of the adequacy of later age income security, the panels also include the level of the national minimum wage and the US\$ 4 poverty line, denoted by the broken line and the dotted line, respectively. Global poverty is conventionally measured by applying an extreme poverty line at US\$ 1.9 per day and a moderate poverty line at US\$ 4 per day. The moderate poverty line is more appropriate to Latin American countries (10). 
FIGURE 2. Within-country inequality in later life income security, distribution of income from retirement benefits and transfers among people aged 65 and over in 2013

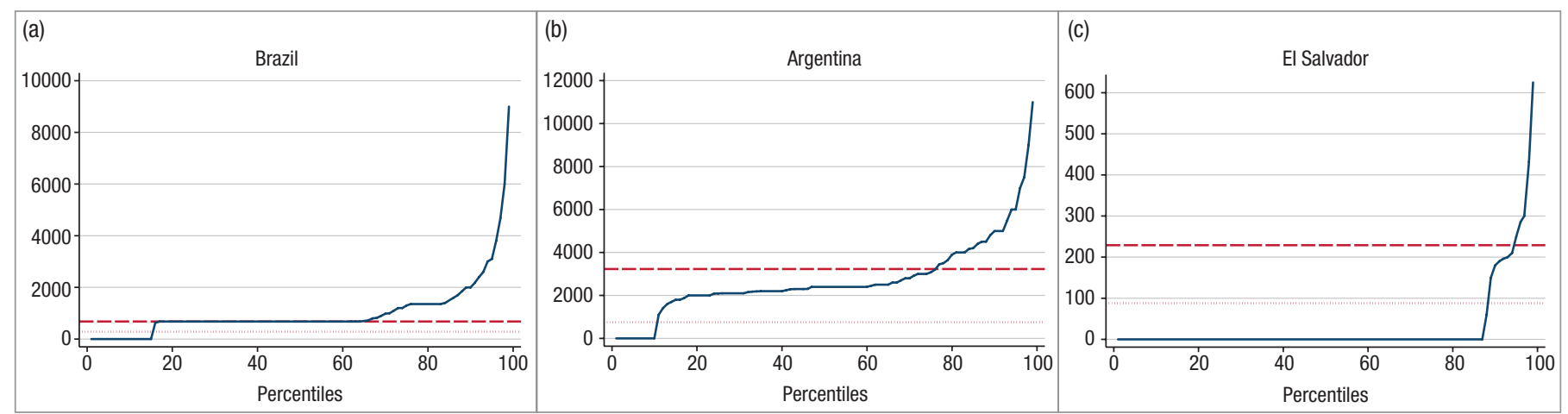

Note: The solid line shows the average income from retirement benefits and transfers in domestic currency for each percentage of the population aged 65 and over, ranked from lowest to highest income. The broken line shows the level of the minimum wage. The dotted line shows the US $\$$ international poverty line.

Source: Prepared by the author based on household survey data: Pesquisa Nacional Por Amostra de Domicilios (PNAD) 2013 for Brazil (https://www.ibge.gov.br/estatisticas/sociais/educacao/9127-pesquisa-nacional-por-amostra-de -domicilios.html?=\&t=downloads); Encuesta Permanente de Hogares Contínua (EPHC) for Argentina 2013 (https://observatorio.unr.edu.ar/encuesta-permanente-de-hogares-eph/); and Encuesta de Hogares de Propósitos Múltiples (EHPM) 2013 for El Salvador (http://www.digestyc.gob.sv/index.php/temas/des/ehpm.html).

All three panels look very similar, with the solid line in the shape of a rough "L" leaning on its longer axis. This is unsurprising given historically high income and wealth inequality in the region and the stratified nature of income security schemes. Roughly $85 \%$ of the population over 65 have no access to income security or receive basic levels of income from retirement benefits and transfers. Income security climbs steeply for the richest $15 \%$ of the population aged 65 and over.

The effects of institutional stratification on income security in later age are not hard to discern from the shape of the solid line in the panels. The left-hand side of the solid lines is populated by groups without any form of income support. In the main, they include informal workers and home workers excluded from formal pension schemes but who are also unable to access old age transfers. This might be because they continue to work and their labor earnings, or the earnings of other members of their household, place them above a minimum threshold. The flat part of the solid lines in the middle of the panels is populated by those able to access old age transfers or in receipt of minimum retirement benefits from occupational schemes or individual retirement plans. The right-hand side of the solid lines is populated by privileged groups from high ranks of the civil service, the military or police, judges, and former parliamentarians.

The three panels of Figure 2 contain information on Brazil, Argentina, and El Salvador. They were chosen to represent similar conditions in the other countries. The key difference across all three countries is in the middle part of the solid line. In Brazil, less than $20 \%$ of the older population is not reached by income security schemes. The middle part of the solid line extends from around the 18th percentile to the 70th percentile and overlaps with the minimum wage line. There is extensive provision of old age transfers in Brazil, through the Beneficio de Prestaçao Continuada, a social assistance transfer for older or disabled people living in poor households, and Previdência Rural, targeting informal workers (11). In addition, a majority of workers affiliated to the private sector pension scheme retire with a minimum guaranteed benefit. All these groups receive income support equivalent to the minimum wage. This explains the extended flat middle part of the distribution (12). In Argentina around $10 \%$ of older people have no access to income security schemes. A variety of old age transfers and minimum retirement benefits from occupational pension schemes explain the gently rising solid line in the middle of the distribution (13). This part of the distribution is above the poverty line but below the level of the minimum wage. In El Salvador, only a small minority of the population aged 65 and over, just above $10 \%$, are in receipt of retirement benefits. Later age income insecurity is the norm.

Inequality in income security in later life is significant in Latin America. It has to do with the tails of the distribution: on the one hand, a substantial group who are excluded from income security schemes, a majority in some countries; on the other hand, a minority, around $15 \%$ of the population aged 65 and over, who are able to capture very high retirement benefits.

\section{GENDER INEQUALITIES IN LATER LIFE}

Latin America shows marked gender inequalities in later life. Women are less likely to receive a retirement benefit than men, and when they do, its value is often lower than for men. On average, women receive lower benefits than men under individual retirement plans because of lower saving density during their working lives and because insurers apply gender-specific mortality tables to calculate annuities. Under individual retirement plans, affiliates have two main options on retirement: to agree a schedule of withdrawals or to use the balance of their accounts to purchase an annuity, a lifetime guaranteed income flow, from insurance companies. In contrast, women are more likely to receive an old age transfer than men and differentials in transfer values are marginal. Overall, women are less income secure than men in later life.

The sources of gender inequalities in income security in later life are associated with gender differentiated societal roles with implications for their engagement in paid employment. Schemes engaged in providing income security in later age can mitigate or reinforce their disadvantage.

Change in gendered societal roles has been slow in the region. Women's labor force participation has risen but with a socioeconomic gradient. Women are more likely to work in low paid and informal jobs, especially in Andean and Central American 
FIGURE 3. Women's retirement benefit and transfer income as a proportion of men's in 2002 and 2016 by quintile of income, Latin America

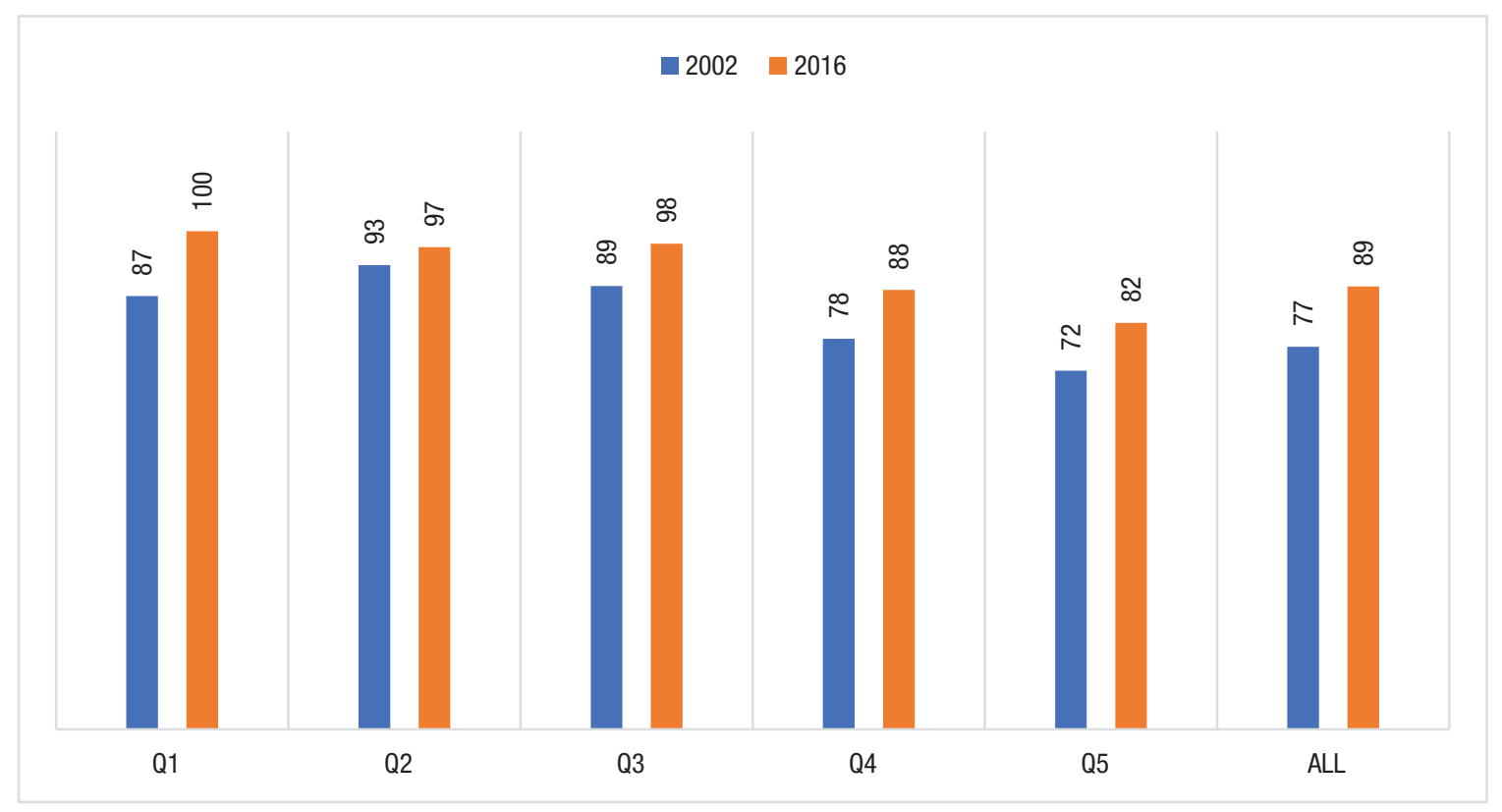

Source: Data extracted from Arenas de Mesa (6) Table IV.12 p.249 and Table IV.13 p. 251 (https://www.cepal.org/es/publicaciones/44851-sistemas-pensiones-la-encrucijada-desafios-la-sostenibilidad-america-latina). Data points are estimates based on household survey data collected in CEPAL's Banco de Datos de Encuestas de Hogares (BADEHOG), including 17 countries (Argentina, Bolivia, Brazil, Chile, Colombia, Costa Rica, Dominican Republic, Ecuador, El Salvador, Guatemala, Honduras, Mexico, Panama, Paraguay, Peru, Uruguay, and Venezuela).

countries. Occupational pension schemes and individual retirement plans are employment-based and therefore unequal distributions of paid and unpaid labor reinforce income security in later age. Recent reforms have acknowledged women's disadvantage through providing additional family-linked credits, recognition of partners, and enforcing the use of unisex mortality rates (Bolivia and El Salvador) $(6,14)$.

The expansion of old age transfers has been extremely effective in reducing gender gaps in later age income security. Figure 3 shows women's income from retirement benefits and transfers as a share of men's in 2002 and 2016 (6). Gender gaps in income rise from the poorest to the richest quintile. Comparison of conditions in 2002 and 2016 confirms the impact of the expansion of transfers; gender gaps in income are marginal for the poorest three quintiles in 2016.

\section{CONCLUSIONS}

This article examined three main dimensions of income security inequality in later life: inequalities in the reach of income security across countries; inequalities in the level of income security within countries; and trends in gender inequalities. There are significant inequalities in the reach of income security across countries. Countries in the Southern Cone and Mexico provide income security to the majority of their citizens, but countries in Central America and the Dominican Republic reach only a fraction of their population. The recent expansion of tax-financed old age transfers has reduced the gaps in reach, especially in Bolivia, Mexico, and Ecuador. Withincountry inequalities in the level of income security provided are marked. The distribution of retirement benefits and transfers in Brazil, Argentina, and El Salvador is skewed in favor of a small minority with disproportionately large benefits. Gender differentials in the level of income security provided have fallen in the last two decades, primarily due to the expansion of taxfinanced transfers.

Despite the fact that, historically, income security in later age has been the focus of social policy in the region, inequalities remain. In the main, they are due to the stratification of the schemes. Until recently, occupational pension schemes and individual retirement plans left many of them behind. These schemes are under pressure. Occupational pension schemes have stagnated in terms of their reach and, despite multiple reforms, continue to absorb large public subsidies (6). Individual retirement plans have not proved popular or effective and are in retreat (15). The rapid expansion of taxfinanced old age transfers has helped mitigate inequalities in access to income security schemes. Leaving aside political and technical challenges, the analysis in the paper points to the policy reform priorities needed to secure a more egalitarian pattern of income security in later age in Latin America. They involve extending the reach of old age transfers to all those groups currently left behind, while at the same time removing public subsidies from the richest retirement benefit recipients. Securing political support for these reforms will be difficult in the region. Policymakers will need to address the criticism that these policy reform priorities involve "levelling down."

In addition, income security in later age will need to address key future challenges. Demographic trends point to the share of the population over 65 rising in a sustained fashion, with implications for the resources needed to ensure their income security and care (16). Changes in the demand for skills and employment have implications for the future of retirement. Climate change and globalization will increasingly tax the capacity of governments to respond to these challenges. 
COVID-19 will involve additional challenges for later age income security schemes. They are likely to reinforce the trends identified in this article. Governments' responses to the immediate health crisis have reinforced and extended tax-financed transfers to vulnerable groups, including old age transfers (17). Several countries have raised the value of old age transfers and others have extended their reach. The economic effects of the pandemic will impact adversely the financial health of occupational pension schemes, through temporary contribution holidays in response to economic disruption, but mainly through rising unemployment (18). Some governments have allowed extraordinary withdrawals from individual retirement plans, which will reduce retirement savings (17). COVID-19 may help accelerate the institutional changes described in this paper.

\section{Conflict of interest. None declared}

Disclaimer. The author holds sole responsibility for the views expressed in the manuscript, which may not necessarily reflect the opinion or policy of the RPSP/PAJPH and/or PAHO.

\section{REFERENCES}

1. Mesa-Lago C. Social security in Latin America: pressure groups, stratification, and inequality. Pittsburgh, PA: University of Pittsburgh Press; 1978.

2. Malloy JM. The politics of social security in Brazil. Pittsburgh, PA: University of Pittsburgh Press; 1979.

3. Mesa-Lago C. Reassembling social security: a survey of pensions and healthcare reforms in Latin America. Oxford: Oxford University Press; 2007.

4. Barrientos A. The changing face of pensions in Latin America: design and prospects of individual capitalisation pension plans. Soc Policy Adm. 1997;31:336-53.

5. Rofman R, Apella I, Vezza E. Beyond contributory pensions: fourteen experiences with coverage expansion in Latin America. Washington, DC: The World Bank; 2015.

6. Arenas de Mesa A. Los sistemas de pensiones en la encrucijada: desafíos para la sostenibilidad en América Latina. Santiago de Chile: Comisión Económica para América Latina y el Caribe; 2019.

7. International Labour Office. World social protection report 2017-19: universal social protection to achieve the Sustainable Development Goals. Geneva: ILO; 2017.

8. Barrientos A. On the distributional implications of social protection reforms in Latin America. In: Cornia GA, editor. Falling inequality in Latin America: policy changes and lessons. Oxford: Oxford University Press; 2014. p. 340-60.

9. Pen J. Income distribution. Harmondsworth: Penguin Books Ltd.; 1971.

10. Castañeda A, Doan D, Newhouse D, Nguyen MC, Azevedo JP, Uematsu H. Who are the poor in the developing world? Policy Research Working Paper. Washington, DC: The World Bank; 2016.
11. Barrientos A. The rise of social assistance in Brazil. Dev Change. 2013;44:887-910.

12. Mesquita ACS, Jaccoud L, dos Santos MPG. Garantia de Renda na Política Social Brasileira: Entre a Proteçao aos Riscos Sociais e o Alivio à Pobreza. Brasília: IPEA; 2010.

13. Bertranou $F$, Cetràngolo $O$, Grushka $C$, Casanova L. Encrucijadas en la seguridad social argentina: Reformas, cobertura y desafios para el sistema de pensiones. Buenos Aires: CEPAL/OIT; 2011.

14. Arza C. Non-contributory benefits, pension re-reforms and the social protection of older women in Latin America. Soc Policy Soc. 2017;16(3):361-75.

15. Kritzer BE, Kay SJ, Sinha T. Next generation of individual account pension reforms in Latin America. Soc Secur Bull. 2011;71:35-76.

16. Cotlear D, editor. Population aging: is Latin America ready? Directions in Development. Washington, DC: World Bank; 2011.

17. Barrientos A. COVID-19 and social protection in Latin America. Bull Lat Am Res. 2020;39(S1):52-5.

18. Arenas de Mesa A. Los sistemas de pensiones en América Latina: institucionalidad, gasto público y sostenibilidad financiera en tiempos de COVID-19. Serie Macroeconomía del Desarrollo, No. 212 (LC/TS.2020/99). Santiago: Comisión Económica para América Latina y el Caribe; 2020.

Manuscript received on 5 November 2020. Revised version accepted for publication on 24 March 2021. 


\section{Desigualdades en la seguridad de los ingresos entre las personas mayores en América Latina}

RESUMEN En este documento se examinan las desigualdades entre las personas mayores en cuanto a la seguridad de los ingresos. Se consideran tres dimensiones de la desigualdad: a) las desigualdades en el acceso al apoyo a los ingresos en los diferentes países y los distintos tipos de planes; $b$ ) las desigualdades en el nivel de apoyo en cada país; y c) las tendencias de las desigualdades en materia de género. La estratificación de los planes contribuye a incrementar la desigualdades de género y en todos los grupos socioeconómicos. Para obtener resultados más equitativos y sostenibles en cuanto a la seguridad de los ingresos de las personas mayores es necesaria una reforma de las políticas dirigida a la incorporación de los grupos excluidos y la eliminación de las ayudas públicas a los jubilados que gozan de privilegios.

Palabras clave Factores socioeconómicos; renta; pensiones; América Latina.

\section{Desigualdades na segurança de renda na terceira idade na América Latina}

RESUMO Este artigo examina as desigualdades na segurança de renda na terceira idade. Três dimensões da desigualdade são analisadas: (i) desigualdades no acesso ao auxílio à renda entre os países e esquemas de benefícios, (ii) desigualdades no grau de auxílio em cada país e (iii) tendências da desigualdade de gênero. A estratificação dos esquemas reforça as desigualdades de gênero e entre os níveis socioeconômicos. Resultados mais igualitários e sustentáveis na segurança de renda para pessoas da terceira idade na América Latina exigem reformas políticas visando à inclusão dos segmentos atualmente excluídos da população e a eliminação de subsídios públicos para aposentados em situação privilegiada.

Palavras-chave Fatores socioeconômicos; renda; pensões; América Latina. 